Apertinances there Unto belonging. We the Subscribers have set our hands and seals this I 8 - Day of March in the Year of our Lord one thousands Eight hundred and Thirteen

Attest

Larkin Livingstone

Ephraim Osgood

Note: The lease having terminated and its provisions having been complied with, the signatures of the parties concerned have been clipped out.

The above agreement fairly bristles with the customs of the times and the idiosyncrasies of the language in rural communities in New England. The situation out of which the lease arose is quite clear. The father of the family has died, his two grown sons have inherited the homestead, "widdow's thirds excepted." The mother occupies her third of the house while the sons lease their two thirds to Timothy Coburn, Jr. It has been suggested that the illiterate wording of the document may be explained by the fact that most of those trained in the legal profession at the time of the Revolution were Loyalists who left the country and a new group of lawyers had not yet been trained to take their places.

Among other documents of interest are apprentice agreements. A large collection of such papers would be invaluable in studying labor conditions. The Society has a few of these, but is anxious to add to the number. Other types of business agreements such as articles of copartnership and articles of incorporation the Society is also anxious to preserve.

\title{
In fltemoriam
}

Charles Curtis Eaton, former librarian of the Graduate School of Business Administration of Harvard University and present assistant dean of the school, died Thursday, March 3, 1932. His death followed an operation resulting from injuries received in the late war in which he served in the front line as lieutenant in the Red Cross Ambulance Corps.

Born in Providence, Rhode Island, January 16, I880, the son of Alice Mary (Dunnell) and Amasa Mason Eaton, he prepared for college at the Cambridge Latin School, and was a member of the class of 1902 of Harvard College. On December 31, I92 I he married Mary Boldt of New York City, who survives him. 
Mr. Eaton was appointed librarian of the Harvard Business School in 1921, and through his efforts there was built up a large collection of books on business. In 1925 he conceived the idea of a business historical society whose aim should be business research and the collecting of data on economic and business situations of the past, and this ultimately led to the organization of the Business Historical Society, which was largely due to his initiative. Although Mr. Eaton severed his connection with the Society in 1929 , the success which the Society has enjoyed is due in very large measure to his enthusiasm and industry in interesting others in the organization during the early days of its existence.

He is not dead, this friend - not dead,

But in the path we mortals tread

Got some few trifling steps ahead

And nearer to the end;

So that you, too, once past the bend,

Shall meet again, as face to face, this friend

You fancy dead.

\section{Robert Louis Stevenson}

On JANUARY 24th, the Business Historical Society lost one of its most eminent members, Paul $M$. Warburg, a banker of international recognition. Mr. Warburg was born in Hamburg in I868, where his great grandfather had founded the banking house of Warburg and Warburg. In 1895, after business experience in London and Paris, he was admitted to partnership in the Warburg firm, then known as M. M. Warburg. While on a trip around the world in $1893 \mathrm{Mr}$. Warburg met Miss Nina Loeb, daughter of Solomon Loeb of the banking house of Kuhn, Loeb and Company, whom he married in 1895. After eight years in Hamburg, they decided to make New York their home and Mr. Warburg became a member of Kuhn, Loeb and Company. In $\mathrm{IgI}_{4}$ at the appointment of President Wilson, he was made a member of the Federal Reserve Board, serving until his resignation in I9I8. In I921 he took up his work as a private banker, founding the International Acceptance Bank, but his interest in the Federal Reserve System continued and he served from I92I to I926 as member of the advisory council of the Federal Reserve Board of which he was president from I 924-1 926. Mr. Warburg was director of many corporations, a few of which were the Baltimore and Ohio Railroad, the 
First National Bank of Boston, Union Pacific Railroad, and the Western Union Telegraph Company. He was interested in many philanthropic activities such as the National Child Labor Committee and Tuskegee Institute. He was author of "The Federal Reserve System - Its Origin and Growth," published in 1930.

\section{Secretary's Column}

\section{ACQUISITIONS}

Since the last publication of the Bulletin the Society has received and gratefully acknowledges the following acquisitions:

From B. F. Blye, Chicago, Illinois, Dawes, General Charles G., Essays and Speeches.

From Prof. William J. Cunningham, Harvard Business School, miscellaneous railroad material relating to the Chicago, Burlington and Quincy Railroad Company, the Northern Pacific Railway Company, and others.

From W. J. Coughtry, Recorder, Delaware and Hudson Railroad, New York, four pamphlets relating to the abandonment of the Honesdale branch of the Delaware and Husdon Railroad.

From J. M. Davis, President, Delaware, Lackawanna and Western Railroad, New York, photostat copy of agreement between Stephen Vail and the Morris and Essex Railroad covering sale of Locomotive no. 246, June 8, 1846 ; photostat copy of table containing statement of labor and materials used by each engine during the year ending December 3I, I 886 .

From F. A. Howard, South Easton, Massachusetts, Parsons, Theophilus, Laws of Business for all the States and Territories of the Union and the Dominion of Canada; Haring, Fred Benson, The Law of Conditional Sales.

From M. B. Jones, President, New England Telephone and Telegraph Company, Boston, three car posters of the Union Railway Company of Cambridge, I 862, I863, and 1866.

From Prof. Malcolm Keir, Dartmouth College, the records of Downing's Drug Store, Hanover, N. H.

From Walter A. Lucas, Hawthorne, New Jersey, miscellaneous railroad reports and pamphlet material on business, political, and social subjects.

From F. H. Meeder, Assistant Comptroller, New York Central Lines, New York, annual reports of the New York Central Lines, together with additional statistical, financial, and corporate information for the use of their officers, for the years 1909-1913, 1915-1920, 1922-1930, inclusive. 